\title{
DIE VORMING VAN 'N EIETYDSE AMPSBEGRIP: JESUS SE OPROEP TOT DISSIPELSKAP
}

\author{
Authors: \\ Robert Jones \\ Ernest van Eck ${ }^{1}$
}

\section{Affiliations: \\ 'Department of New \\ Testament Studies, \\ University of Pretoria, \\ South Africa}

\section{Correspondence to:}

Ernest van Eck

email:

ernest.vaneck@up.ac.za

\section{Postal address:}

Faculty of Theology,

University of Pretoria

Lynwood Road, Hatfield

0083, Pretoria, South Africa

\section{Keywords:}

church office; discipleship; institutionalization; cultural constructs; Jesus movement

\section{Dates:}

Received: 31 May 2010

Accepted: 14 Aug 2010

Published: 01 Oct. 2010

How to cite this article: Jones, R. \& Van Eck, E., 2010, 'Die vorming van 'n eietydse ampsbegrip: Jesus se oproep tot dissipelskap', HTS Teologiese Studies/ Theological Studies 66(1) Art. \#878, 10 pages. DOI: 10.4102/hts.v66i1.878

\section{This article is available}

http://www.hts.org.za

\section{Note:}

Hierdie artikel is 'n verwerkte weergawe van Robert Jones se PhD-proefskrif getiteld

'Die vorming van 'n eietydse ampsbegrip: Jesus se oproep tot dissipelskap', voorgelê in die Departement Nuwe-

Testamentiese Wetenskap, Fakulteit Teologie, Universiteit van Pretoria, onder die promotorskap van prof. dr Ernest van Eck.

(C) 2010. The Authors. Licensee: OpenJournals Publishing. This work is licensed under the Creative Commons Attribution License.

\section{ABSTRACT}

The forming of a contemporary understanding of church office: Jesus' calling to discipleship

This article aimed to examine the Nederduitsch Hervormde Kerk van Afrika's (NHKA) understanding of church office, and measure it against 'office' or ministries in the New Testament, and more specifically against Jesus' calling to discipleship in Mark 8:34. The relevance of the historical Jesus for contemporary church theology is indicated by the 'essential' (Sache) continuity that exists between the historical Jesus and the church today. The article concludes that Jesus' calling to discipleship in Mark 8:34 implies a certain understanding of office. The essence of this calling is servitude based on self-denial, the taking up of one's cross, and the following of Jesus.

Subsequently, a few remarks are made on the NHKA's understanding of church office, as described in the NHKA church ordinance. The aim is for these remarks to serve as a guideline for the NHKA to form a contemporary understanding of church office. The concluding remarks have been derived from the results of the study on Jesus' calling to discipleship, with the aim of ensuring that the NHKA serves and works in correspondence with the Word of God. This service occurs in a world very different from the one in which Jesus lived and served.

\section{INLEIDING}

Die Nederduitsch Hervormde Kerk van Afrika (NHKA) se ontstaan kan teruggevoer word na die kerkhervorming van die 16de eeu. Dít impliseer dat die NHKA hom ook met die uitspraak van die hervorming assosieer, te wete dat ' $n$ kerk van die hervorming ' $n$ kerk is wat homself voortdurend na die Woord van God hervorm. ${ }^{1}$ Hiermee erken die NHKA dat kerkwees nie ' $n$ statiese verskynsel is nie, maar gebeure. Daarom kan die kerk nie in enige van die sake waaroor hy besluite neem werklik by 'n finale besluit uitkom nie. Dit geld onder andere vir die kerk se nadenke oor Skrifbeskouing, ekklesiologie en ampsbegrip.

Wat betref sy ampsbegrip steun die NHKA baie sterk op die kerkhervormers, veral Calvyn. Die deuteroPauliniese sowel as pastorale briewe (1 en 2 Timoteus en Titus) oefen ook 'n sterk invloed op die kerk se ampsbegrip uit (kyk Nederduitsch Hervormde Kerk van Afrika 2009:93-111).

Die vraag is of die kerk daarby kan volstaan om sy ampsbegrip te begrond in die deutero-Pauliniese briewe, die pastorale briewe, en in dit wat eksponente van die 16de-eeuse kerkhervorming onder die amp verstaan het. Die waarheid is dat bogenoemde ampsbegrip ' $n$ interpretasie is van die Jesusgebeure. In wese beteken dit dat die kerk se ampsbegrip ' $n$ interpretasie van ' $n$ reeds gevormde interpretasie is.

Hierdie artikel gaan uit van die standpunt dat dit wat Jesus in sy prediking oor die koninkryk van God verkondig, as sleutel dien om die wesenlike verstaan van die amp in die kerk te verwoord. Op grond van kontinuïteit tussen die Pauliniese teologie en die Jesus-saak (Bartchy 2009:12), sou die Pauliniese briewe en die bedieninge in die Pauliniese gemeentes ook tot die verstaan en bedoeling van die amp kon bydra.

Verder gaan hierdie artikel van die vooronderstelling uit dat die kerk op grond van die verskynsel van institusionalisering en de-institusionalisering telkens nuut oor die inkleding en wese van die amp behoort na te dink. Die vraag is of die kerk in hierdie proses van institusionalisering en deinstitusionalisering ${ }^{2}$ van charisma steeds in sy ampsbegrip en die praktiese inkleding daarvan Jesus se opdrag tot dienswerk weerspieël. Dié vraag word beantwoord deur aan te toon dat Jesus se oproep tot dissipelskap in Markus 8:34' $n$ bepaalde ampsbegrip impliseer. Die relevansie tussen die historiese Jesus en kerklike teologie word ook aangetoon.

\section{RELEVANSIE VAN DIE ‘HISTORIESE JESUS’-ONDERSOEK VIR DIE KERK VANDAG}

Die lewe van die historiese Jesus, sowel as die vertellings oor Hom soos dit in die kanonieke evangelies opgeteken is, speel af in 'n wêreld ver verwyderd van vandag wat betref taal, sosiale gebruike, gewoontes en kultuur. Te midde van hierdie verskille is daar tog ook sekere ooreenkomste, wat daarop dui dat daar 'n kontinuïteit sowel as 'n diskontinuïteit tussen 'toe' en 'nou' bestaan. Dit is na my mening nodig om

1.Ecclesia reformata semper reformanda est per verbo Dei.

2.Institusionalisering kan beskryf word as die proses wat plaasvind wanneer' $n$ groep hom van ander groepe afgrens deur op grond van sy eie (nuwe) identiteit en visie $n$ struktuur daar te stel waarbinne die nuwe identiteit en visie die beste tot uiting kom. Institusionalisering en strukturering gaan altyd hand aan hand, en vind plaas binne $n$ bepaalde konteks, wat hoofsaaklik deur die eise van die samelewing en tyd bepaal word. Wanneer hierdie eise verander en die groep nie meer' $n$ invloed in die samelewing het nie, word die aanvanklike struktuur gewysig om 'n nuwe manier in hierdie veran struktuur gewysig om op hn nu manier in hierdie verander ent de-institusionalisering plasgevind, wat heel warskynlik weer institusionalisering tot gevolg sal hê. 
hierdie kontinuïteit en diskontinuïteit in ag te neem ten einde die relevansie van die historiese Jesus vir die kerk vandag aan te toon.

Van Aarde (2000:550) betoog dat 'historiese Jesus'-navorsing help om groter duidelikheid te kry oor die oorleweringsproses van die tradisies wat om Jesus ontstaan het, sowel as die manier waarop dit in die kanonieke evangelies geopenbaar is. Daarom is die 'historiese Jesus'-ondersoek onontbeerlik vir die literêre en historiese bestudering van die Nuwe Testament. Die evangeliste berig vanuit 'n na-Pase-perspektief oor die voor-Pase(historiese) Jesus. Die evangeliste het hulle na-Pase-verstaan van Jesus teruggeprojekteer op die voor-Pase-lewe van Jesus. Dit is moeilik om duidelik tussen die voor-Pase- en na-Pase-elemente in die evangelies te onderskei; die voor- en na-Pase-gebeure kan nie van mekaar geïsoleer word nie.

Van Aarde en Van Eck (2007:7) noem die vier verskillende prentiies wat in die kanonieke evangelies van Jesus geteken word, die kondensasiepunt tussen die tekstuele wêreld, ${ }^{3}$ die kontekstuele wêreld ${ }^{4}$ en die referensiële wêreld. ${ }^{5}$ Elkeen van die evangelies het sy eie tekstuele en kontekstuele wêreld, terwyl hulle ' $n$ referensiële wêreld deel. Nie een van die prentiies wat die evangeliste van die historiese Jesus teken, kan as algemeen geldend of as norm gebruik word om die relevansie van die historiese Jesus vir kerklike teologie aan te toon nie (kyk Petersen 1985:7; Van Eck 1995:73-74). Volgens Van Aarde (2000:552) lê die relevansie van die 'historiese Jesus'-ondersoek vir die kerk in 'n saaklike kontinuïteit tussen die historiese Jesus en die kerk vandag.

Crossan (1998:22-31) is ook van mening dat navorsing oor die historiese Jesus relevant is vir die kerk vandag. Hiervoor bied Crossan drie redes aan, naamlik 'n historiese, ${ }^{6}$ etiese $^{7}$ en teologiese rede ${ }^{8}$ (Crossan 1998:22-31). Na my mening is dít ook die grense waarbinne Crossan meen die rekonstruksie van die historiese Jesus veronderstel is om plaas te vind.

Drie redes kan aangevoer word waarom die 'historiese Jesus'ondersoek relevant is vir die kerk vandag. Die eerste is dat Jesus en sy dissipels konkrete historiese figure was, en daarom histories ondersoek kan word. Geen historiese gebeure, plek of persoon is van historiese ondersoek gevrywaar nie. Hierdie opmerking impliseer dan ook die tweede rede, naamlik dat Jesus se uitsprake en opdragte ' $n$ werklikheid was, en daarom vir die kerk vandag geaktualiseer behoort te word. Om die Jesus-saak

3.Die tekstuele wêreld van 'n evangelie word deur die teks van die evangelie geskep. Die tekstuele wêreld van Markus bevat byvoorbeeld geen na-opstandingsverskyning van Jesus of 'n vertelling oor die hemelvaart nie, terwyl Lukas albei bevat.

4.Die kontekstuele wêreld van ' $\mathrm{n}$ evangelie dui op die sosiale konteks (Sitz-im-Leben) van die eerste lesers (hoorders) van die evangelie. Hierdie konteks het 'n beslist invloed op hoe die Jesusverhaal aangebied word. Die feit dat elke evangelie sy eie Leitmotiv het, beklemtoon die feit dat elke evangelie in/vir'n ander konteks geskry is.

5.Met referensiële wêreld word bedoel die wêreld waarna die teks verwys. In die geval van die evangelies is die referent van die teks die verhaal van die historiese Jesus.

6.Jesus en sy volgelinge is figure wat in die geskiedenis gefunksioneer het, en kan daarom histories bestudeer word. Omdat die geskiedenis van die historiese Jesus bekend is en daar verskeie historiese dokumente daaroor bestaan, is dit moontlik
om dit vandag te rekonstrueer. Sonder die evangelies sou dit nie moontlik wees om 'n rekonstruksie van die historiese Jesus te maak nie (kyk Crossan 1998:22).

7.Daar bestaan soms 'n diskrepansie tussen teologie en geskiedenis. Geloof op sigself kan nie historiese feite verifieer of as vals bewys nie. Crossan brei hierdie argument uit deur na die voorbeeld van goddelike konsepsie te verwys. Hy vergelyk die goddelike konsepsie van Augustus met die van Jesus, en voer aan dat dit óf die goddelike konsilis 1998:28). Wanneer Christene as historici hierdie gebeure rondom Jesus in so 'n 1998:28). Wanneer Christene as historici hierdie gebeure rondom Jesus in so
mate isoleer dat dit volgens hulle die enigste historiese weergawe van soortgelyke mate isoleer dat dit volgens hulle die enigste historiese weergawe van soortgelyke
verhale, of die enigste weergawe van die waarheid is, word dit vir Crossan 'n etiese verhale, of
probleem.

8.Vanuit 'n teologiese hoek verkies Crossan (1998:30) die term 'historiese Jesus' bo die term 'werklike Jesus'. Laasgenoemde kan nie gekonstrueer word nie. Die term 'historiese Jesus', daarenteen, dui op die Jesus van die verlede wat interaktief 'hick gekonstrut is op grond van bes die manier waarop Hy gesterf het. Hierdie ondersoek is, aldus Crossan (1998:30), baie belangrik en bied 'n uitdaging vir die Christelike geloof. te aktualiseer, word aanvaar dat daar ' $n$ kontinuïteit' bestaan tussen die literêre en teologiese inhoud van die dokumente wat ons van Jesus se lewe op aarde vertel. Hierdie kontinuïteit moet verleng word na waar die kerk vandag sy roeping uitvoer. Derdens kan gewys word op die kontinuïteit tussen historie en teologie. Die 'historiese Jesus'-ondersoek help om wat in die verlede gebeur het op die hede te projekteer.

Die kerk is verbind aan dit waarvoor Jesus gestaan het. Omdat die gebeure in die geskiedenis nie geverifieer of as vals afgemaak kan word bloot op grond daarvan dat ons hier met die evangelie te doen het nie (kyk Crossan 1998:26-29), sal ons moet erken dat die kerk, en daarom ook die kerklike kerugma, nie bo kritiek verhewe is nie.

Na my mening is 'historiese Jesus'-navorsing wél relevant vir die kerklike teologie vandag. Hierdie relevansie is geleë in die saaklike kontinuïteit tussen dit wat die Jesus-saak genoem kan word, en dit wat die kerk vandag behoort te verkondig en te leef. Op grond hiervan kan die gevolgtrekking ook gemaak word dat Jesus se verstaan van dissipelskap relevansie het vir die hedendaagse verstaan en inkleding van die amp.

\section{DIE BEWEGING RONDOM JESUS}

Jesus $^{10}$ en sy dissipels is nie ' $n$ groep wat, soos ander soortgelyke groepe soos die Sadduseërs, ${ }^{11}$ Selote, ${ }^{12}$ Fariseërs $^{13}$

9.In 'historiese Jesus'-navorsing is daar nie eenstemmigheid oor die antwoord op die vraag of daar' $n$ kontinuïteit of diskontinuïteit tussen die historiese Jesus en kerklike Olo 作 die Jesus van die geloof. Funk begrond hierdie diskontinuitteit in sy oortuiging dat die verkondiger van die koninkryk die verkondigde geword het, in plaas daarvan dat dit wat Jesus verkondig het die koninkryk van God - die fokus van die verkondiging van die vroeë kerk gebly het. Die visie van Jesus is met die persoon van Jesus vervang. Volgens Funk moet die koninkryk van God, en nie Jesus nie, die objek van geloof wees. Schmithals oordeel dat Jesus se verkondiging apokalipties-eskatologies van aard was, en dat sy opstanding in sy apokaliptiek veranker is. Die Paasgebeure, en nie Jesus se lewe nie, is die veronderstelling van die kerk. Crossan (kyk Van Aarde toe, en die Jesus van nou. Die historiese Jesus is volgens hom' $n$ feit, en die evangelies' $n$ interpretasie van hierdie feit. ' $n$ Mens glo nie in feite nie, maar in die interpretasies daarvan. In wese is elke feit ' $n$ interpretasie, maar daar is altyd ' $n$ relasie tussen feit en interpretasie. Op sy beurt oordeel Van Aarde (2000:565, 567) weer dat daar enersyds 'n saaklike kontinuïteit bestaan tussen die historiese Jesus en die opgestane Christus, en andersyds tussen die historiese Jesus en Paulus. Jesus sien Homself as kind van sy Vader, en Paulus praat van om 'in Christus' te wees. Die kerk is volgens Van Aarde daarom 'n alter-Israel. Volgens Van Aarde bestaan daar ook 'n saaklike kontinuïteit tussen die historiese Jesus en die kerklike teologie.

10. Hiermee word nie die indruk geskep dat Jesus doelbewus ' $n$ groep gestig het waarvan mense deel kon word nie. Dit wat Jesus verkondig het, het spontaan 'n groep rondom Hom laat ontstaan. Onderskeid word ook getref tussen 'die beweging rondom Jesus' en 'die Jesusbeweging'. Eersgenoemde verwys na Jesus na-Pase-beweging wat as gevolg van die Paasgebeure ontstaan het.

11.Die Sadduseërs was die dominante politieke party in die eerste eeu in Judea, afkomstig van die aristokrasie en ryk priesterlike families. Hulle was in beheer van die tempel en tempelmaatreëls; het hoë ampte in Jerusalem beklee, en ouing was hulle konserwatief, en het die godsdienstige wette soos die Sabbat streng toegepas. Hulle het verder net die Tora aanvaar, en nie die mondelinge wet van die Fariseërs ook nie. Met die vernietiging van die tempel in $70 \mathrm{nC}$ het die Saddusese beweging heel waarskynlik tot niet gegaan. Hulle het die opstanding uit die dood ontken, sowel as die aanbidding van die afgestorwenes (nekromansie) (Dunn 1977:104; Van Aarde 1994:120).

12.Die Selote was ' $\mathrm{n}$ religieus-politieke party wat om en by $67-68 \mathrm{nC}$ as ' $\mathrm{n}$ rebellegroep ontstaan het nadat Vespasianus Galilea stelselmatig in $67 \mathrm{nC}$ verower en Judea begin binneval het (die sogenaamde Joodse Oorlog). Ten tyde van die Joodse Oorlog het die Selote die priesters in Jerusalem aangeval, die tempel oorgeneem, en hul heie hoëpriester aniestel. Spoedig het daar'n sterk nasionalisme onder hulle ontstaan en het hulle gepoog om hul doelwitte deur geweld te bereik. Die Selote kies 'n nuwe hoëpriester, wat terselfdertyd ook die nuwe regeringsleier was, omdat die 'n nuwe hoëpriester, wat terselfdertyd ook die nuwe regeringsleier was, omdat die
godsdiens en politiek van daardie tyd nie van mekaar losgemaak kon word nie (Dunn godsdiens en politiek van daardie tyd nie van mekaar losgemaak kon word
1977:104; Horsley \& Hanson 1985:216-219; Van Aarde 1994:155-157).

13.Die Fariseërs was ' $\mathrm{n}$ groep wat hulle veral op grond van die reinheidsmaatreëls van die tempel afgesonder het ' $n$ Leermeester-dissipel-verhouding was belangrik in hierdie groep. Dit is nie presies duidelik waarvan hulle hulle afgesonder het nie. Hierdie groep kom waarskynlik uit die Hassidim, wat gedurende die Makkabe opstand radisionele Joods godsdiens na vore gekom het. Die Farisese ideologie kan voorgestel word as ' program om die reinheidsmaatreëls van die tempel na die huishouding van elke 
en Esseners ${ }^{14}$ in isolasie bestaan het nie. Die belangrike vraag om te beantwoord is waar Jesus en sy dissipels tussen hierdie groepe inpas. Die groep rondom Jesus het heel moontlik die vorm aangeneem van 'n rabbi en sy dissipels.

Dunn (1977:105-106) is van mening dat daar nie na die groep rondom Jesus as ' $n$ gemeenskap verwys moet word nie. Die kriterium om ' $\mathrm{n}$ dissipel van Jesus te word was om die wil van God te doen. Daar was geen toelatingsvereistes om tot hierdie groep toe te tree nie. Jesus se dissipels moes nie sekere opdragte uitvoer waarby die groep waarvan hulle deel is, kon baat vind nie. Hulle moes bloot deel in Jesus se missie, naamlik die verkondiging van God se koninkryk. Die beweging rondom Jesus word dus as ' $n$ beweging eerder as ' $n$ gemeenskap beskryf (kyk Dunn 1977:106).

Die familie is in die eerste-eeuse Mediterreense wêreld as die mees dominante sosiale instelling beskou. Volgens Malina (1995:108) kan die beweging rondom Jesus na analogie van die familie as ' $n$ 'fictive kinship' beskryf word. In hierdie 'fictive kinship' was daar geen amptelike struktuur of hiërargie nie, omdat dit vir Jesus nie oor die vestiging van strukture gegaan het nie, maar eerder oor die verkondiging van die koninkryk van God en 'n dienooreenkomstige lewe.

Anders as die gemeenskap van sy tyd, het Jesus nie sosiale gebruike as iets beskou wat grense tussen mense tot gevolg moes hê nie. Wanneer Jesus byvoorbeeld saam met mense geëet het, het Hy nie die ete beskou as iets wat sosiale grense skep nie. Hy het ' $n$ openheid getoon en daarin iets van die koninkryk van God laat manifesteer. Om in Jesus se tyd saam met iemand om die tafel te wees het beteken dat daar vertroue, vrede en broederskap was tussen diegene rondom die tafel. Jesus vereenselwig Hom dus met sondaars en tollenaars wanneer Hy saam met hulle eet. Om hierdie rede is Hy ook ' $n$ wynsuiper en vriend van tollenaars genoem (Matt 11:19). Deurdat Jesus Homself met hierdie mense vereenselwig het, het $\mathrm{Hy}$, volgens Dunn (1977:162), tydens hierdie maaltye die oopheid van die beweging rondom Hom (fictive kin group) getoon wat 'n weerspieëling was van God se houding teenoor mense. Dunn (1977) verwoord dit soos volg:

But Jesus' tablefellowship was marked by openness, not by exclusiveness. That is to say, Jesus' fellowship meals were invitations to grace, not cultic rituals for an inner group which marked them off from their fellows.

(Dunn 1977:162)

Dit is juis hierdie oopheid van die beweging rondom Jesus wat dit van ander bewegings van die tyd onderskei het.

(Footnote 13 cont...)

wetsgetroue Jood uit te brei. Omdat hulle so sterk op die onderhouding van die Tora klem lê, stel hulle 'n klomp wette in (die sogenaamde 'heinings om die Wet'), sodat niemand dalk onbewus die Tora oortree nie. Die Fariseërs het geen direkte gesag gehad nie. Hulle het'n stryd gevoer om op plaaslike leiers en die bevolking invloed uit te oefen. Dít het meegebring dat Jesus vanaf die begin van sy bediening met die Fariseërs gebots het (Dunn 1977:104: Van Aarde 1994:109-112). Volgens Saldarin (1988:144) phaas Markus die Farise rs altyd in Galiea, en is hulle nie in Jeusalem (1988:144) Plas Merulem (Mik 3:6) en die skifgeleerdes (Mark 2:16). Die Faniseers was primer $h$ rellyieuse beweging en nie 'n politieke groepering nie. Hulle was die beskermers van 'n sekere soort gemeenskap. Jesus het hierdie siening van die gemeenskap uitgedaag deurdat Hy hul reinheidswette geïgnoreer het (die was van hande, vas, reinheidsmaatreëls en Sabbatswette). Volgens Saldarini (1988:150-151) het Jesus en die Fariseërs se konflik nie oor teologiese kwessies gehandel nie, maar oor wie in beheer is van die gemeenskap. Jesus het nie eer en aansien in die gemeenskap gehad nie, omdat Hy nie uit 'n vooraanstaande familie gekom het nie. Daarom het die feit dat Hy gepreek het teenkanting van die Fariseërs ontlok. In vergelyking met Markus brei evangelie is (kyk byvoorbeeld Matt 23).

14.Die Esseners ontstaan uit dieselfde groep as die Fariseërs, naamlik die Hassidim. Hulle is baie strenger as die Fariseërs wat wetsgehoorsaamheid betref. Volgens Filo en Josefus het die groep uit 4000 mans bestaan wat nie getroud was nie om só kontak met onreinheid te voorkom. Van hulle was egter tog getroud. Hierdie groep het in die geheim bestaan. Hulle glo dat die siel ná die dood bevry word. Die regverdige se siel gaan hemel toe, terwyl die bose mens se siel gestraf word. Die Esseners se leringe toon sterk ooreenkomste met dié van Qumran. Hul teologie toon die gedagte van twee geeste - die engel van lig en die engel van duisternis tool van lig en die engel van duisternis wat as bemiddele n eskatologiese gemeensap. Intern was hierdie groep baie goed georganisee en het 'n gestruktureerde gemeenskap uitgemaak (Dunn 1977:104; Van Aarde 1994:158-160)
In hierdie verband kan die stelling ook gemaak word dat Jesus getrou was aan die Tora, maar dat Hy Hom nie by die Joodse wette geskaar het nie. Jesus het die Tora anders as sy Joodse teenstanders geïnterpreteer. Jesus leer dat God in die eerste plek besorg is oor mense (kyk Van Eck 2007:501-504, 2009:470471). Jesus verstaan God anders as sy teenstanders. Jesus se teenstanders is onder die indruk dat God eerder besorg is oor die nakoming van wette. Jesus maak dit egter duidelik dat God eerder besorg is oor mense en hul welwees..$^{15}$ Jesus se verstaan van God was dus inklusief (kyk Bailey 2008:194-195; Cuppit 2001:58; Van Eck 1995:181-182, 2009:470).

Die boodskap van Jesus se prediking aan sy volgelinge kan saamgevat word in die stelling dat Jesus die koninkryk van God verkondig het. Hy roep mense op om in gehoorsaamheid aan God te leef. In die indikatief van sy prediking noem Jesus wat dit is wat God van mense verwag, en in die imperatief van sy prediking roep Hy mense op om te leef soos wat God vra.

Geen ampsbegrip of model vir bediening in 'n kerk kan na die beweging rondom Jesus teruggevoer word nie. Tog is daar na my mening ' $n$ implisiete ampsbegrip in Jesus se oproep tot dissipelskap. Hierdie stelling sal in die volgende gedeelte toegelig word.

\section{JESUS SE OPROEP TOT DISSIPELSKAP}

Jesus se oproep tot dissipelskap binne die groter struktuur van die Markusevangelie

Deur op die ruimtes in Markus te konsentreer, deel Van Iersel (1982:136, 1983:42, 1989:18-30) die evangelie soos volg in:

$\begin{array}{ll}\text { Woestyn } & \text { (Mark1:1-1:13) } \\ \text { Galilea } & \text { (Mark 1:14-8:26) } \\ \text { Op weg } & \text { (Mark 8:27-10:52) } \\ \text { Jerusalem } & \text { (Mark 11:1-15:45) } \\ \text { Graf } & \text { (Mark 15:46-16:8) }\end{array}$

In Markus kom dissipelskap in drie leringe van Jesus ter sprake, naamlik Markus 8:34-38; 9:35-37 en 10:42-45. Hierdie leringe van Jesus maak deel uit van die 'op weg'-gedeelte in Markus. Die betekenis van hierdie drie leringe word bepaal deur die gedeelte van Markus waarin dit voorkom (Mark 8:22-10:54). Die 'op weg'-gedeelte bind die twee hoofgedeeltes van Markus, te wete Galilea en Jerusalem, aan mekaar, en funksioneer inhoudelik as ' $n$ ruimtelike oorgang vanaf ' $n$ nieverstaan van Jesus se identiteit (Galilea) na dit wat Jesus se identiteit wél is. Die struktuur van Markus bring die nieverstaan van die dissipels na vore. Aan die begin van die 'op weg'-gedeelte vertel Markus van die genesing van ' $n$ blinde man (Mark 8:22-26). In hierdie gedeelte moet die blinde herhaaldelik genees word om te kan sien. Die doel van hierdie vertelling in Markus is om te toon hoe vlak die dissipels se insig in hierdie stadium van die verhaal lê. Hulle 'sien' nie. Jesus moet hulle herhaaldelik leer, want hulle sukkel om 'genees' te word.

Dit wat Jesus van hulle verwag, word op ' $n$ treffende manier in die 'op weg'-gedeelte beskryf in nóg ' $n$ vertelling van ' $n$ blinde se genesing (Mark 10:46-52). In hierdie verhaal het die blinde egter 'n naam - Bartimeus. Bartimeus word onmiddellik genees, en hy volg Jesus. Dít is die punt wat Jesus wil hê sy dissipels moet

15. Hier kan na die begrippe simboliese en sosiale universum uit die kennissosiologie verwys word. Volgens Berger en Luckmann (1975:118-120) funksioneer die simboliese universum ('sacred canopy') van die enkeling en 'n gemeenskap as in beskermende komel wat institusionele orde betref. Die sosiale universum is ' $n$ beskermende koepel wat institusionele orde betref. Die sosiale universum is
die wêreld waarin mense leef. Die sosiale universum word dus op grond van die verstaan van die simboliese universum gekonstrueer. Die Jode het God teen die agtergrond van die orde van die skepping (simboliese universum) verstaan. God is 'n God van orde, en daarom moet alles in die samelewing (sosiale universum) georden wees om by die eer van God te pas. Dít het tot gevolg gehad dat sekere grense neergelê is ten einde hierdie orde te handhaaf. Hierdie grense is geopenbaar in die onderskeid tussen byvoorbeeld rein en onrein. God is dus uit die oogpunt van heiligheid verstaan (Lev 10.2). In die gemeenskap (sosiale uit die oogpun) universum) is hierdie orde deur die Joodse wette gehandhaaf. Jesus het God egter het nie die simboliese universum teen die agtergrond van God se heiligheid gesien nie, maar eerder teen die agtergrond van sy barmhartigheid. 
bereik. Daarom leer Jesus hulle in die 'op weg'-gedeelte wat dissipelskap werklik beteken. Die twee blindes se genesing dien dus as inleiding en afsluiting van hierdie gedeelte in Markus.

Die 'op weg'-gedeelte, waarin Jesus sy dissipels leer wat sy koms na die aarde, en meer spesifiek sy lyding, beteken, kan soos volg ingedeel word:

$\begin{array}{ll}\text { Blinde se genesing } & \text { (Mark 8:22-26) } \\ \text { Lydensaankondiging } & \text { (Mark 8:31) } \\ \text { Misverstand } & \text { (Mark 8:32) } \\ \text { Lering } & \text { (Mark 8:34-9:1) } \\ \text { Lydensaankondiging } & \text { (Mark 9:31) } \\ \text { Misverstand } & \text { (Mark 9:32) } \\ \text { Lering } & \text { (Mark 9:35-37) } \\ \text { Lydensaankondiging } & \text { (Mark 10:33-34) } \\ \text { Misverstand } & \text { (Mark 10:35-37) } \\ \text { Lering } & \text { (Mark 10:38-45) } \\ \text { Blinde se genesing } & \text { (Mark 10:46-52) }\end{array}$

Ná elkeen van Jesus se drie lydensaankondigings word dit duidelik dat die dissipels nie verstaan nie. Ná die eerste lydensaankondiging roep Petrus vir Jesus eenkant en berispe Hom (Mark 8:32-33); ná die tweede lydensaankondiging stry die dissipels onder mekaar oor wie die belangrikste is (Mark 9:34), en ná die derde lydensaankondiging wil Johannes en Jakobus aan Jesus se linker- en regterkant sit wanneer Hy as koning heers (Mark 10:35-37).

Die dissipels verstaan dus nie wat Jesus van hulle verwag nie. Elke keer wanneer hulle ná Jesus se lydensaankondigings nie verstaan nie, verduidelik Jesus vir hulle wat Hy hulle wil leer en wat dissipelskap beteken. Wanneer Jesus die vraag beantwoord oor wie die belangrikste in die koninkryk van die hemel is, roep Hy ' $n$ kind, wat ' $n$ randfiguur in die samelewing was, nader om vir die dissipels in hul onkunde te wys wie regtig die belangrikste in die koninkryk van die hemel is (Mark 9:36-37). Jesus maak dit ook duidelik dat elkeen wat groot wil wees, 'n dienaar moet wees (Mark 10:43-44). In sy antwoord aan Jakobus en Johannes maak Jesus dit duidelik dat dit nie gaan oor watter posisie ' $n$ mens beklee nie, maar eerder dat jy Jesus volg. Van Eck (1995) verduidelik Jesus se 'op weg wees' vanaf Galilea na Jerusalem soos volg:

Jesus' way is a way from Galilee, through suffering in Jerusalem and back to Galilee. As Jesus suffered by being killed for his 'way' in the Gospel, so will the disciples suffer in the future by walking on the same 'way' (cf. Mk 13:9-13).

(Van Eck 1995:24)

Die inhoud van Jesus se drie leringe ná elke lydensaankondiging, en die dissipels se misverstand, kan soos volg saamgevat word:

- In die eerste lering (Mark 8:34-9:1) verduidelik Jesus dat om werklik ' $n$ dissipel van Hom te wees, ' $n$ mens bereid moet wees om in jouself te sterf en ander belangriker as jyself te ag. Mense wat ter wille van hulself die lewe op aarde belangriker ag as om vir Jesus te volg, kan nie 'n dissipel van Jesus wees nie. Wie ter wille van Jesus in die oë van die wêreld gespot word en skande oor hulself bring, is werklik sy dissipels, en sal die ewige lewe ontvang. Die belangrikste in hierdie lering van Jesus is dus om diensbaar te wees teenoor God en teenoor die wêreld.

- In die tweede lering (Mark 9:35-37) leer Jesus sy dissipels dat iemand wat die belangrikste wil wees homself moet verneder deur almal se dienaar te word. Dit hou ook verband met Jesus se vorige lering van selfverloëning (Mark 8:34). Jesus gebruik dan 'n kind, wat ' $n$ randfiguur ('nobody') in die eerste-eeuse Mediterreense wêreld was en geen status gehad het nie, om vir die dissipels te sê dat iemand wat soos die kind geen begeerte aan aansien en status het nie, die belangrikste is in God se koninkryk. As iemand 'n dissipel van Jesus wil wees, moet hy dus soos die kind geen begeerte na status hê nie, maar nederig wees soos ' $\mathrm{n}$ dienskneg. In hierdie lering is die belangrikste dus nederigheid en bereidheid tot diens.
- In die derde lering (Mark 10:38-45) verduidelik Jesus dat status nie by iemand pas wat sy dissipel wil wees nie. In plaas daarvan om na status te streef, moet 'n dissipel van Jesus diensbaar wees deur bereid te wees om vir ander te ly. Boonop is niemand bo ' $\mathrm{n}$ ander verhewe nie, maar eerder diensbaar. Ook in hierdie lering maak Jesus dit dus duidelik dat diensbaarheid die belangrikste saak is as iemand sy dissipel wil wees.

In al drie dié leringe gaan dit oor diens. In die eerste lering word dit aan die hand van kruisopneming, selfverloëning en navolging beskryf. In die tweede lering gaan dit daaroor om nie die belangrikste te wees nie, maar laaste te wees, te dien, en nie ' $n$ begeerte te hê om belangrik te wees nie (om soos ' $n$ kind te word). In die derde lering gaan dit daaroor om eerder te dien as om te wil heers.

Jesus maak dit dus in al drie hierdie siklusse duidelik dat iemand wat Hom wil volg, moet dien soos wat Hy in sy lyding gedien het. Navolging beteken dus navolging in die lyding van Jesus.

\section{Oproep tot dissipelskap}

Malina (2001:115) verdeel Jesus se oproep tot dissipelskap (Mark 8:34) in vier dele, naamlik oproep tot navolging, selfverloëning, kruisopneming en navolging. Myns insiens funksioneer dit wat Malina as die eerste deel van Jesus se oproep stel, nie werklik as deel van die oproep nie, maar eerder as ' $n$ inleiding tot die drie vereistes van navolging wat daarop volg. Dit kan soos volg voorgestel word:

'As iemand agter My aan wil kom, moet hy homself verloën,

sy kruis opneem en My volg.

Vervolgens word daar kortliks aandag gegee aan die drie dele van Jesus se oproep tot dissipelskap.

\section{Selfverloëning}

Soos vroeër genoem is, was die familie in die eerste-eeuse Mediterreense wêreld die mees dominante sosiale instelling. Die familiestruktuur het aan sy lede sekuriteit en identiteit gegee. Met selfverloëning het Jesus nie net bedoel dat iemand wat agter Hom wil aankom homself moet verloën nie, maar ook die familie waarvan hy of sy deel is. Dit was abnormaal vir iemand om van die familiestruktuur losgemaak te word, omdat dit skande oor hierdie persoon sowel as oor die familie sou bring. Wanneer ' $n$ man van sy familie losgemaak is, moes hy by ' $n$ ander portuurgroep ('kin group') inskakel om weer 'n plek in die samelewing te kon hê. Jesus sê dan dat wanneer iemand ter wille van Hom van sy familie afstand doen, hy meer huise, broers, susters, moeders, kinders en eiendom kry (Mark 10:29-30). Wanneer iemand dus vir Jesus volg, is hy nie alleen nie, maar het hy 'sosiale sekuriteit', ten spyte daarvan dat hy sy familie agtergelaat het. Malina (2001:132) stel dit soos volg: 'But in the refashioned synoptic storyline, the outcome of such self-denial, then, would be a new ingroup and affiliation to a fictive kin-group' ( $\mathrm{vgl}$ Matt 18:19-22; Mark 10:17-22; Luk 9:57-62).

Jesus se bedoeling met selfverloëning is dus nie net dat daar van aardse rykdom afstand gedoen moet word nie, maar ook van patriargale mag. Om dít binne die sosiale konteks van die eersteeeuse Mediterreense wêreld te plaas beteken dus dat dit wat die wêreld as die belangrikste beskou, in hierdie geval die familie, minder belangrik is as om Jesus te volg. ${ }^{16}$

Die nuwe 'familie', oftewel 'fictive kinship', negeer dus die patriargale struktuur.

16.Afgesien van die Sinoptiese tradisie, beweer Malina (2001:115-116) dat die evangelie van Tomas (EvTom 55,101 ) ook van selfverloëning melding maak. In evangelie van Tomas (EVTom 55,101) ook van selfverloëning melding maak. In familie. 


\section{Kruisopneming}

Jesus se oproep om jou kruis op te neem moet verstaan word teen die agtergrond van die versaking van die patriargale familie. In die plek van hierdie familie staan die nuwe 'familie' ('fictive kinship') waartoe Jesus mense oproep.

Iemand wat die keuse maak om Jesus te volg maak terselfdertyd die keuse om sy/haar kruis op te neem. Myers (1988:267) betoog dat die keuse om jou kruis op te neem die volgende beteken: Elkeen wat groot wil word, moet 'n dienaar wees (Mark 10:43-44); patriargale stelsels wat 'n wig tussen die eenheid en gelykheid van die nuwe gemeenskap indryf, mag nie toegelaat word nie (Mark 10:1-12), en die kinders, wat die minste van die minste is, moet in die middelpunt van die gemeenskap gestel word. In die nuwe gemeenskap moet toelating en aanvaarding beskikbaar wees aan almal; is daar nie meer plek vir ekonomiese klas en voorregte nie (Mark 10:17-31), en mag leierskap nie as instrument van dominansie gebruik word nie (Mark 10:35-41).

Die belangrikste uit hierdie punte wat Myers noem, is dat daar gelykheid is in die gemeenskap van Jesusnavolgers. Alhoewel leierskap ook in so 'n groepering nodig is, mag dit nie tot verhewenheid bo ' $n$ ander lei nie. Die wese van hierdie groepering is inklusief, omdat niemand van die nuwe huisgesin van God ('fictive kin group') uitgesluit mag word nie.

Om jou kruis op te neem sou ook beteken om oneer en skande oor jouself te bring. Daar is reeds aangevoer dat die familie die dominante sosiale instelling in die eerste-eeuse Mediterreense wêreld was. Om jou eer te beskerm deur skande te vermy was in die destydse samelewing die belangrikste. Wanneer daar skande oor ' $\mathrm{n}$ familie gekom en die eer van die familie só aangetas is, is die eenheid en aansien van die familie ook daardeur aangetas. Die familie as sosiale struktuur is dus ernstige skade aangerig. ${ }^{17}$ Beskou in die lig van navolging, beteken dit dus om in Jesus se lot te deel; in jouself te sterf; nederig eerder as belangrik te wees, en daarom ook jou naaste eerste te stel en self laaste te wees.

\section{Navolging}

Wanneer Markus sy gemeenskap oproep om Jesus te volg, doen hy dit volgens Matera (1987:55) as pastor, omdat Markus se gemeenskap nie werklik die volle betekenis van dissipelskap verstaan het nie.

Wanneer die dissipels geroep word om Jesus te volg, is dit Jesus wat as die soewereine God mense roep om Hom te volg. Mense

17. Malina het reeds in 1981 'n model oor eer en skande in die eerste-eeuse Mediterreense wêreld ontwikkel. As deel van hierdie model tref hy onderskeid tussen twee verskillende tipes eer, en beskryf dit met die terme 'ascribed honor' en 'acquired honor'. Iemand kry 'ascribed honor' wanneer hy in 'n welgestelde familie, of ' $n$ familie met ' $n$ goeie naam, gebore word. 'Acquired honor', daarenteen, kan op 'n daaglikse grondslag bekom of verloor word. Oor uitdagings vir eer sê Malina (1981) die volgende: (1) Byna elke interaksie met mense buiten die familie het die potensial om ' $\mathrm{cu}$ utdaging vir eer te wees, (2) in die proses om het die potensiaal om hitdaging vir eer te wees, (2) in die proses om eer te bekom of teveloor met lemand moet iets teenoo iemand anders se of doen; dit wat gese of geinterpreteer is, moet as 'n uitdaging beoordeel word; ' $n$ teenantwoord moet gegee word, en hierdie teenantwoord moet deur die publiek geëvalueer word, (3) uitdagings en teenantwoorde daarop moet in die openbaar geskied, (4) uitdagings en reaksies kan net tussen sosiaal gelykes plaasvind. lemand in ' $\mathrm{n}$ laer klas in die samelewing kan nie die eer van 'n koning uitdaag nie. Wanneer so ' $\mathrm{n}$ persoon vir die koning ' $\mathrm{n}$ belediging sou skree en die koning hom sou straf, word dit nie as 'n reaksie op 'n uitdaging beskou nie, maar bloot as straf vir wat hy verkeerd gedoen het en (5) daar word uit die oogpunt van eer en skaamte tussen mans en vroue onderskei. Volgens Malina is dear gedrag eer en skante tussen wat pas by mans, en gedrag wat pas by vie ee het nie. Hy sewel dat vioue se samelewing, en moederskap gesetel is. Crook (2008) voer aan dat uitdagings wél tussen verskeie klasse in die samelewing voorkom. Dit is volgens hom ook nie meer die individu wat op eer aanspraak maak of eer toeken nie, maar die 'public court of opinion'. Op grond hiervan stel Crook voor dat Malina se twee terme, naamlik 'ascribed honor' en 'acquired honor', verander word. In die lig daarvan dat die klem van die individu na die 'public court of opinion' verskuif, stel Crook verder voor dat die twee terme wat Malina gebruik, met 'attributed honor' en 'distributed honor' vervang moet word. 'Attributed honor' is die eer wat die 'public court of opinion' an iemand gee wanneer hy in' $n$ welgestelde familie gebore word court of opinion' an ieme we were ('ascribed honor). 'Distributed hon 'is die eer wat daagliks deur die court of opinion' ander 'n weldaad doen ('acquired honor'). Die 'public court of reputation' besluit of bepaalde gedrag - ongeag status, rykdom, geslag of persoon - eervol is of nie. wat tot hierdie verhouding geroep word, kan dit afwys, maar kan nie die verhouding self skep nie. Die belangrikste van die dissipels se roeping is om Jesus tot aan die einde te volg en op weg na Jerusalem by Hom te bly. Hulle moet bereid wees dat Jesus se lot ook hulle lot word, omdat hulle nie meer hulself eerste stel nie, maar in hulself sterf en ander belangriker ag as hulself.

Uit bogenoemde blyk duidelik dat daar ' $\mathrm{n}$ verband bestaan tussen die Christologie van Markus, en dissipelskap. Hierdie twee ontmoet mekaar, volgens Matera (1987), in die kruis. Hy verwoord dit soos volg:

Just as one cannot understand who Jesus is apart from the cross, so one cannot grasp the true meaning of discipleship unless he or she is willing to follow Jesus 'on the way'.

(Matera 1987:54)

Om Jesus te volg word dus voorafgegaan deur te verstaan wie Hy werklik is. Dit kan nie los van die kruis van Christus gebeur nie.

Markus wou sy gemeenskap laat besef dat navolging, wat gevolglik ook dissipelskap genoem kan word, beteken om te lewe op die manier wat Jesus van hulle verwag - soos Hy. Hierdie leefwyse kan saamgevat word in twee dinge waarvan Jesus se lewe getuig het: gehoorsaamheid aan God tot aan die einde, en ' $n$ lewe wat geheel en al uit diensbaarheid bestaan.

\section{Dissipelskap in die sosiale konteks van Jesus}

In die eerste-eeuse Mediterreense wêreld is kinders as 'nobodies' beskou. Hulle het geen aansien of belangrikheid in die samelewing gehad nie. Crossan (1991:269) verduidelik die plek van kinders in die samelewing soos volg: 'To be a child was to be a nobody, with the possibility of becoming a somebody absolutely dependant on parental standing in the community.' Wanneer Jesus aan sy dissipels verduidelik wie in die koninkryk van God belangrik is, gebruik Hy 'n kind - 'n 'nobody' in die oë van die wêreld (Mark 9:36-37; 10:13-16). Só maak Jesus dit duidelik dat wie vir God belangrik is, nie noodwendig vir die wêreld belangrik is nie. In die koninkryk van God moet mense ook bereid wees om 'nobodies' te word en 'nobodies' onvoorwaardelik te aanvaar, omdat ook húlle vir God belangrik is.

Navolging van Christus geskied dus in die gees van aanvaarding van hulle wat deur die wêreld verwerp word. In navolging van Jesus is niemand dus verhewe bo ' $n$ ander nie; almal is gelyk.

Vir dissipels beteken navolging van Jesus dat hulle in die nuwe huishouding van God soos kinders word; soos mense wat geen status het in die oë van die wêreld nie, maar wél in die oë van God. Waetjen (1989:167) verwoord hierdie gedagte soos volg: 'Also in the next episode (Mk 10:13-16), Jesus indicates that in their innocence and openness, children manifest the qualities of authentic humanness which is characteristic of God's rule.'

Dissipelskap in die sosiale konteks van Jesus beteken dus om 'n 'nobody' te wees in die oë van die wêreld, en belangrik te wees in die koninkryk van God.

\section{Dissipelskap in Markus}

Matera (1987:17) beweer dat dissipelskap deel is van die rede waarom die Markusevangelie geskryf is. Dit is omdat Markus se gemeenskap vergeet het dat die kruis die kern is van dissipelskap. ${ }^{18}$ Markus herinner dan sy gemeenskap dat die

18. Hier kan ook na die insette van William Wrede en Theodore Weeden verwys word. Volgens Wrede (1971) is Markus eerder 'n verduideliking van Jesus se identiteit as wat dit' $n$ objektiewe weergawe van sy lewe is. Om hierdie stelling te staaf wys as wat di h obje wys Wrede op die Messian te bly. Wrede bew Jesus na vore getree het, omdat die kerk besef het dat Hy werklik die Messias is. Die vroeë kerk het geoordeel dat daar in Jesus se aardse lewe wél bewyse was dat Hy die Messias is. Omdat daar in die evangelie niks hiervan te vinde is nie, het die vroeë kerk geoordeel dat Jesus sy Messiasskap tydens sy lewe op aarde geheim gehou het. Dit was hierdie Messiaanse geheim wat Markus in sy evangelie 
kern van dissipelskap daarin lê dat iemand wat Jesus wil volg, sy kruis moet opneem.

Matera (1987) brei bogenoemde stelling verder uit wanneer hy dissipelskap ook verbind met ' $n$ verstaan van wie Jesus werklik is. Hy stel dit soos volg:

It is the evangelist' way of saying that the risen Lord can only be met by those who follow the way of discipleship marked out by the crucified one during his earthly ministry.

(Matera 1987:18)

Die rol van die dissipels in Markus se evangelie kan myns insiens aan die hand van ' $n$ golfbeweging beskryf word. Die dissipels word nie deurentyd as positiewe karakters geteken nie, maar soms ook as negatief wanneer hulle nie die werklike betekenis van dissipelskap verstaan nie. Matera (1987:18) verduidelik hierdie 'blindheid' van die dissipels as 'n literêre instrument wat Markus gebruik om sy gemeenskap op die werklike omvang en betekenis van dissipelskap te wys. Só roep Markus sy gemeenskap op tot dissipelskap. Hy gebruik die dissipels se tekortkominge om Christene tot ware dissipelskap op te roep; om Hom te volg soos wat Jesus bedoel het sy dissipels Hom moes volg toe Hy hulle geroep het. Hieruit blyk ook dat die soeke na mag en aansien nie pas by iemand wat Jesus werklik wil volg nie. In aansluiting by die stelling dat Markus die dissipels se beeld gebruik om sy gemeenskap tot navolging/ dissipelskap op te roep, verwys Matera (1987:46) ook na ' $n$ stelling van Best (1981:12), naamlik dat dissipelskap ook berus op die gewilligheid om God se hulp te aanvaar.

Dissipelskap in Markus beteken dus om te verstaan en te 'sien' wie Jesus werklik is. Na aanleiding van die verband tussen Jesus se lydensaankondigings en sy leringe aan sy dissipels, soos hierbo uiteengesit, kan die stelling gemaak word dat ' $n$ mens nie werklik los van die kruis kan verstaan wie Jesus is nie. Die regte verstaan van wie Jesus is, het tot gevolg dat dissipelskap as diens teenoor God en teenoor die medemens begryp word. Hierdie diensbaarheid beteken om van jouself af te sien en nie status en aansien na te jaag nie. Markus se bedoeling met dissipelskap is dus om te 'sien' wie Jesus werklik is en op grond daarvan diensbaar te wees.

\section{BEGRONDING VAN `N AMPSBEGRIP}

Die oortuigings van die kerk is blootgestel aan kritiek, waarteen die kerk hom moet kan handhaaf. As rede hiervoor kan aangevoer word dat die gebeure rondom die historiese Jesus nie geverifieer of as vals afgemaak kan word bloot omdat dit evangelie is nie. Die kerk moet erken dat sy verkondiging nie bo kritiek verhewe is nie (kyk Crossan 1998:26-29).

Die kerk is die draer van die boodskap van Jesus Christus - van sy lewe en van wat Hy onderrig het. Daarom is dit nodig dat die kerk met die Jesus-saak kontinuïteit behou, en wel in die vorm van ' $n$ saaklike kontinuïteit tussen die kerk se verkondiging, en die historiese Jesus. Die saak waaroor dit vir Jesus gegaan het, dien as grondslag vir die kerk se verkondiging, maar ook vir die kerk se nadenke. Die historiese Jesus, en daarom ook die saak

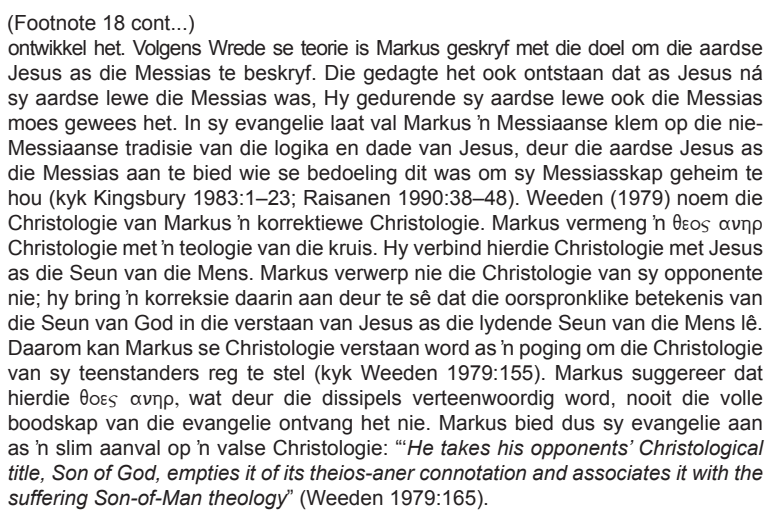

waaroor dit vir Jesus gegaan het, moet aktueel gemaak word vir vandag. Die waarde van die ondersoek na die historiese Jesus vir die kerk vandag lê ook daarin dat dit kan help om dit wat in die verlede gebeur het op die hede te projekteer, en só antwoorde op die kerk se vrae te bied.

Dit gaan in die kerk steeds oor die geloof in die historiese Jesus en in die boodskap wat Hy gepreek het. Die Woord van God dien as die enigste maatstaf wanneer die kerk uitsprake maak. Daarom kan die stelling gemaak word dat Jesus se oproep tot dissipelskap, en sy bedoeling daarmee, relevant is vir die hedendaagse verstaan en inkleding van die amp.

Daar kan dus met stelligheid beweer word dat daar ' $n$ implisiete ampsbegrip is in Jesus se oproep tot dissipelskap, en dat hierdie ampsbegrip as begronding vir 'n eietydse ampsbegrip dien.

\section{Mag en gesag}

In die beweging rondom Jesus het Jesus opgetree met gesag, synde die gestalte van God se gesag (Matt 28:18). Hierdie gesag het Jesus ook aan sy dissipels gegee om mee op te tree (Mark 3:15; Luk 9:1). Alhoewel Jesus hierdie gesag aan die dissipels verleen het, was Hy sterk gekant teen die misbruik van mag en gesag wanneer ander mense daardeur te na gekom is (Matt 5:3a; 5:24-26; 5:39-40; 5:43-48; 18:23-34; 20:16; 22:1-10; Mark 10:31; 10:42; 12:1-12; Luk 6:20b; 6:27-28; 6:29-30; 12:57-59; $13: 30 ; 15: 14-24)$. Hierdie stelling word telkens bevestig wanneer Jesus sy dissipels ná sy lydensaankondigings leer, en hulle dit misverstaan.

Jesus se siening van mag en gesag word in die evangelie van Markus beskryf wanneer Markus sy lesers tot dissipelskap oproep. Hy gebruik die dissipels se tekortkominge om sy lesers op die werklike betekenis van dissipelskap te wys, naamlik diensbaarheid teenoor God en teenoor jou naaste deur selfverloëning. Hieruit blyk duidelik dat die soeke na mag en aansien nie by dissipelskap pas nie. Dissipelskap sluit ook die bereidwilligheid in om jou afhanklikheid van God te besef.

\section{Diensbaarheid}

Ampswerk is gesetel in charismata wat God deur sy Gees aan gelowiges gee. Die amp of ampsdraer op sigself het geen betekenis nie. Die betekenis van die amp lê juis in die dienswerk, oftewel ampswerk, wat verrig word. Hierdie gedagte staan ook in kontinuïteit met die Jesus-saak deurdat dit vir Jesus nie daaroor gegaan het dat dit belangrik is om ' $n$ amptelike posisie te beklee nie, maar eerder dat gelowiges diensbaar teenoor God en medemens moet wees. Die dienskarakter van ampswerk wys weg van die amp en ampsdraer, en wys heen na God en medemens aan wie die ampsdraer op grond van die uitoefening van sy amp diensbaar is. Dit gaan dus hier onder andere oor selfverloëning (Mark 8:34). Die amp is dus nie 'n abstrakte aangeleentheid nie, maar vind gestalte in diens aan mekaar en aan God.

In die beweging rondom Jesus het die dissipels nie gesagsposisies beklee nie. Van hulle is dissipelskap en diensbaarheid verwag. Daarom is diensbaarheid die wese van die uitoefening van die amp in die kerk vandag.

\section{Institusionalisering en struktuur}

Jesus het geen intensie gehad om 'n kerk te stig nie. Hy het ook geen kerklike model of kerklike strukture nagelaat met die bedoeling dat dit vir die kerk gebruik moes word wat later gevolg het nie. Hy het die koninkryk van God verkondig, en iets van die koninkryk van God sigbaar gemaak hier op aarde, deur die manier waarop Hy geleef het. Hy was diensbaar, en het mense geleer wat God van hulle verwag en hoe om diensbaar te wees in die oë van God, wat nie dieselfde was as diensbaarheid in die oë van die wêreld nie. 
Jesus se prediking het nie tot ' $n$ leer en verskeie teologiese dogmas verstar nie. Hy het die evangelie verkondig en het dit vir mense in hul eie leefwêreld konkreet en relevant gemaak. Om werklik ' $n$ dissipel van Jesus te wees het nie beteken dat iemand in ' $\mathrm{n}$ struktuur moes inpas of aan sekere toelatingsvereistes moes voldoen nie. Die beweging rondom Jesus was 'n oop beweging, en nie eksklusief nie. Die 'toelatingsvereiste' om tot hierdie groep te behoort was om die wil van God te doen. Dít maak van mense dissipels; nie lede van 'n sekere organisasie met ' $n$ duidelik geformuleerde doel nie. Jesus het een doel gehad, en dit was om die koninkryk van God te verkondig (kyk Van Eck 2009:466-475).

Institusionalisering vind plaas in ' $\mathrm{n}$ spesifieke sosiale konteks, en kan soos volg beskryf word: 'n Bepaalde vorm van gedrag, wat gegrond is in charisma, dien as die impuls wat daartoe lei dat ' $n$ bepaalde groep hom van die res van die samelewing afgrens. Hierdie proses gee aan die groep identiteit, en help om homself in ' $n$ bepaalde struktuur in te rig wat die beste daartoe sal bydra dat hy doeltreffend funksioneer. Hierdie institusionalisering en struktuur skep die ruimte waarin die groep sy visie en boodskap die beste kan uitleef om sy doel te bereik.

Wanneer die eise van die omstandighede verander, of wanneer die groep sy doel bereik het, is die kans goed dat ' $\mathrm{n}$ nuwe visie en doel geformuleer word ten einde by die nuwe omstandighede of nuwe eise aan te pas. Die nuwe visie lei tot de-institusionalisering, waarna die nuwe omstandighede dan weer institusionalisering tot gevolg het.

Institusionalisering kan dus gedefinieer word as die proses waar 'n bepaalde struktuur in ' $n$ spesifieke sosiale konteks geskep word waarin 'n groep sy visie en doel die beste uitleef.

Die proses van institusionalisering, de-institusionalisering en herinstitusionalisering vind deurlopend in sosiale groepe plaas. Veranderde sosiale eise van die samelewing en spesifieke kontekste waarin groepe hul visie uitleef, gee aanleiding tot die deurlopendheid van die proses. Die skep en wysiging van strukture in ' $n$ bepaalde groep is deel van die institusionaliseringsproses (kyk Dreyer 2002:625). As 'n groep in die samelewing, is die kerk ook aan hierdie proses blootgestel.

Institusionalisering en strukturering vind dus binne-in die kerk plaas. Hiervan is die kerkorde ' $n$ goeie voorbeeld, omdat die kerkorde, tipies van 'n instituut, riglyne neerlê waarbinne die kerk op sy oproep tot dissipelskap antwoord. Die uitdaging vir die kerk lê juis daarin om die charisma waarmee God mense toerus in so ' $\mathrm{n}$ mate te institusionaliseer dat dit konkreet en doeltreffend aan dienswerk gestalte gee. Hierdie dienswerk moet ook telkens wanneer dit geïnstitusionaliseer word, in 'n saaklike kontinuïteit met die historiese Jesus staan. Die saak wat Jesus verkondig het, moet dus die grondslag wees van die institusionalisering in die kerk vandag.

Dit is uiters belangrik om raak te sien dat geen struktuur wat in die kerk gebruik word (kerkorde, erediensorde, inrigting van kerklike vergaderings, ampstruktuur) presies in die Skrif voorkom soos wat dit in die kerk gebruik word nie. Die strukture in die kerk vandag kan hoogstens uit die Skrif afgelei word en funksioneel in werking gestel word. Daarom moet die strukture so ingerig wees om die beste uitvoering te gee aan die opdrag tot diens wat ons in die Skrif ontvang. Voorts moet die struktuur wat daargestel word doelmatig wees om te verseker dat die kerk, binne sy geïnstitusionaliseerde strukture, die beste aan dienswerk gestalte gee sodat dit op die doeltreffendste manier moontlik geskied.

Kerklike strukture is mensgemaakte konstrukte wat gevorm word om charisma in 'n bepaalde tyd en konteks te institusionaliseer, om op die beste manier moontlik diensbaar te wees in die kerk, wat in daardie tyd en konteks sy roeping as kerk van Jesus Christus moet uitleef. Daar moet egter daarteen gewaak word dat hierdie konstruk gemistifiseer en sodoende tot kanon verhef word. Dan word ' $n$ struktuur in stand gehou ten koste van die doeltreffende funksionering van dienswerk in die kerk. Wanneer die eise van die tyd verander, moet hierdie strukture daarmee tred hou en aanpasbaar wees om ná deinstitusionalisering weer in so ' $n$ mate geïnstitusionaliseer te word om die beste op die eise van die tyd te reageer. Dít moet gebeur sonder om die wesenlike van die ampsbegrip, naamlik diensbaarheid, te verloor.

Dit is van die uiterste belang om ook die volgende gevare van institusionalisering uit te wys. Eerstens hou institusionalisering die gevaar van mags- en gesagsmisbruik in. Mense word deel van 'n groep, en streef na hooggeplaaste posisies in die groep, omdat hulle reken dat hulle self daarby kan baat vind. Die tweede gevaar van institusionalisering is dat kulturele konstrukte in die pad van die visie en doel van die groep kan kom staan. In sommige gevalle beteken die nastreef van ' $n$ groep se visie of doel dat lede van die groep gedeeltelik of heeltemal met ' $n$ tradisie, oftewel 'n kulturele konstruk, moet breek. ${ }^{19}$ Eeue oue kulturele konstrukte word dikwels in stand gehou veral omdat dit geborgenheid verleen aan optrede onder die 'beskerming' van die konstrukte. Hierdie konstrukte word nie bevraagteken nie omdat dit deel geword het van ' $n$ bepaalde kultuur.

Derdens kan strukture wat as gevolg van institusionalisering ontstaan mense enersyds in staat stel om doeltreffender te funksioneer, maar kan dit andersyds ook uiters beperkend wees. Strukture wat mense beskerm en vir hulle ' $n$ ruimte skep waarin hulle kan leef, laat mense makliker optree en die visie van hul groep uitleef. Strukture werk egter dikwels ook negatief in op die doeltreffende funksionering van sake.

' $n$ Vierde gevaar van institusionalisering is dat ' $n$ bepaalde struktuur soms belangriker word as die doel of visie van die groep. Aksies van die groep word gesmoor, en die doel van die groep stol in ' $n$ struktuur. In hierdie geval lei institusionalisering tot stagnasie, terwyl die struktuur ten alle koste in stand gehou word. Die struktuur word gemistifiseer en tot kanon verhef, omdat dit geborgenheid gee aan die mense wat in hierdie struktuur optree en nie wil verander nie.

\section{EIETYDSE AMPSBEGRIP}

\section{Implisiete ampsbegrip}

Geen ampsbegrip word direk na die beweging rondom Jesus teruggevoer nie. Tog, op die vraag of daar 'n implisiete ampsbegrip is in Jesus se oproep tot dissipelskap, en die inrigting in die beweging rondom Hom, is die antwoord ja. Hierdie implisiete ampsbegrip in Jesus se oproep tot dissipelskap moet as basis dien wanneer die kerk oor sy ampsbegrip besin. 'n Eietydse ampsbegrip behoort dus gevorm te word op die grondslag wat Jesus in sy oproep tot dissipelskap gelê het.

Hierdie saak kan verder gemotiveer word deur op die kontinuïteit te wys tussen die historiese Jesus en wat daarná gekom het, naamlik die kerk. Hierdie saaklike kontinuïteit met die Jesus-saak is geleë in die boodskap wat die kerk verkondig.

'n Positiewe antwoord op die oproep tot dissipelskap is uiters belangrik vir die verstaan van die amp, omdat ampswerk niks anders is as dienswerk nie.

Die implisiete ampsbegrip in Jesus se oproep tot dissipelskap moet dus deel uitmaak van die ampsbegrip van die kerk.

19.Wat Jesus van mense gevra het wat Hom wou volg, het teen die destydse sosiaal aanvaarbare norm ingedruis. Volgelinge van Jesus moes die bestaande oortuigings oor die belangrikste sosiale instelling van hul tyd, naamlik die familie verak oor die belan ne deel word van die nuke huisgesin van vad. Eers wanneer mense bereid was om deel word van die nuwe huisgesin van God. 


\section{Institusionalisering, struktuur en orde}

Die struktuur waarin 'n groep sy visie uitleef, moet deur die visie en doel van die groep bepaal word. Die struktuur moet dus so ingerig word dat dit nie die groep strem nie, maar eerder die ruimte skep waarin die visie en doel die beste bevorder kan word. Die visie van die groep oefen dus na my mening die grootste invloed uit op die struktuur. Die struktuur kan nie bepalend wees vir die visie van die groep nie. Indien dít gebeur, sou die visie en die strewe om hierdie visie uit te leef deur die struktuur gestrem word. Die struktuur word dan in stand gehou ten koste van die visie en doel van die groep.

Wanneer 'n struktuur nie meer daartoe bydra dat die visie van die groep nagestreef word nie, maar eerder verlammend inwerk op die groep se aksies, is dit nodig dat 'n nuwe struktuur gevestig word waarin die groep se aksies weer momentum kry om die groep se doel te bereik. Hierdie stelling bevestig weereens die sirkelgang van institusionalisering, de-institusionalisering en herinstitusionalisering.

Bogenoemde geld ook vir die kerk. In die kerk behoort strukture nie ten koste van die verkondiging van, en positiewe antwoord op, Jesus se oproep tot dissipelskap in stand gehou te word nie. Die positiewe antwoord op Jesus se oproep tot dissipelskap moet (in elke nuwe konteks) tot 'n bepaalde struktuur lei. 'n Struktuur hou egter ook die gevaar in dat dit die werk in die groep, en daarom ook die ampswerk in die kerk, kan smoor. Tog kan struktuur ook nie sonder meer weggelaat word nie omdat dit orde bring. Daar bestaan dus ' $n$ fyn balans tussen orde en struktuur - 'n balans wat deurgaans gehandhaaf moet word.

Wanneer charisma geïnstitusionaliseer word om aan ampswerk uitvoering te gee, is dit nie die struktuur wat as maatstaf van institusionalisering moet dien nie, maar eerder dit wat die Skrif leer. Jesus se oproep tot dissipelskap, en diensbaarheid as deel van dissipelskap, behoort te bepaal hoe die struktuur moet lyk. Die struktuur moet momentum gee aan dienswerk eerder as om dit te smoor.

Daar moet daarteen gewaak word dat gebruike van die verlede tot kanon verhef word en dienswerk smoor. Institusionalisering en strukturering moet van so ' $\mathrm{n}$ aard wees dat wanneer dit nie meer doeltreffend aan dienswerk gestalte gee nie, dit geëvalueer word en, indien nodig, gede-institusionaliseer, en later herinstitusionaliseer word. Institusionalisering mag nie stagnasie beteken nie. Institusionalisering moet as die aanpassing van strukture vir doeltreffende dienswerk verstaan word. In hierdie aanpassing is dit nie nodig dat die kern van die saak waaroor dit vir Jesus gegaan het, naamlik diensbaarheid teenoor God en medemens, in die slag bly nie.

Die kerk se antwoord op dienswerk lê nie in die instandhouding van strukture nie, maar eerder in die navolging van Jesus Christus as deel van dissipelskap. Om op Jesus se oproep tot dissipelskap te antwoord, en só aan dienswerk gestalte te gee, het struktuur definitief ' $n$ plek. Struktuur help om orde te skep in ' $\mathrm{n}$ instituut - in hierdie geval die kerk.

Die institusionalisering van charisma is nie iets abstrak wat in die lug ronddryf nie. Dit kry konkrete inhoud in die kerk se ampswerk, en word gebou op Jesus se oproep tot dissipelskap. Sodra ons met institusionalisering in die kerk te make het, word ' $n$ kerkraad gevorm wat uit die predikant, ouderlinge en diakens bestaan. Na aanleiding van die visie van die kerk, naamlik om as dissipels in en aan die wêreld en aan God diensbaar te wees, gee die kerkraad die toon aan. Die kerkraad moet dus voortdurend, op grond van Jesus se oproep tot dissipelskap, die rigting aanwys waarin die gemeente moet beweeg.

Daarom is dit van die uiterste belang dat ampswerk in die kerk nie as gevolg van institusionalisering stagneer nie.

\section{Funksioneel en kontekstueel}

Omdat institusionalisering van charisma beteken dat die ampsbegrip in ' $n$ struktuur veranker is, bestaan die moontlikheid dat ampswerk in hierdie struktuur kan stol. Die kerk is nie staties nie, maar dinamies. Daarom kan ampswerk ook nie staties wees nie; dit moet in elke situasie dinamies en diensbaar wees. Die amp moet dus funksioneel wees.

'n Funksionele ampsbegrip dui daarop dat ampswerk op grond van die institusionalisering van sekere charismata die middelpunt bly, en dat die amp of ampsdraer self nie tot 'n middelpunt verhef word waarsonder die kerk nie kan bestaan nie. God hou die kerk in stand deur dienswerk wat in die kerk verrig word. Hierdie dienswerk word in die charismata begrond wat God deur sy Gees aan gelowiges gee. Hierdie charismata word geïnstitusionaliseer, en vind dan gestalte in die amp en ampsdraers. Die funksionele karakter van die amp verhoed dat die klem op die amp en ampsdraers self val, en plaas dit eerder op die ampswerk, oftewel dienswerk, wat in die kerk verrig word. ${ }^{20}$

Afgesien van die funksionele karakter van die amp, is dit noodsaaklik dat die amp ook 'n kontekstuele karakter toon. Institusionalisering van charisma vind nie in ' $n$ lugleegte plaas nie, maar in 'n sekere konteks in die leefwêreld van die kerk. Die plek waar die kerk diensbaar moet wees en die evangelie moet laat hoor, is die wêreld. Daarom is dit noodsaaklik dat die kerk ook relevant moet wees in die wêreld waarin hy diensbaar is. Indien die kerk nalaat om te verseker dat hy in pas is met die wêreld waarin hy leef, word die kerk ál verder verwyderd van die wêreld aan wie hy die evangelie verkondig en diensbaar moet wees.

Hierdie stelling kan egter nie ongekwalifiseerd gemaak word nie. Die kerk bly natuurlik ook anders as die wêreld, en kan nie die wêreld as maatstaf gebruik vir hoe hy oor homself dink nie. Die Skrif as norma normans is steeds die maatstaf wanneer die kerk oor homself en sy werk hier op aarde nadink. Dít geld ook vir die ampsbegrip.

Indien die kerk nie meer in staat is om die amp, soos wat dit in 'n sekere situasie ingerig is, uit te voer nie, is dit noodsaaklik dat die manier waarop ampswerk gedoen word, in die nuwe konteks aangepas sal word.

Die Skrif as norma normans is steeds vir die kerk die maatstaf wanneer hierdie aanpassing, oftewel herinstitusionalisering, plaasvind. Die rede hiervoor is dat diens aan die Woord steeds die grense bly waarbinne die kerk hom inrig in, en diensbaar is aan, die wêreld.

Amp, struktuur en institusionalisering is drie sake wat nie van mekaar losgemaak kan word nie. Charisma behoort funksioneel en kontekstueel geïnstitusionaliseer te word. Dít lei tot diensbaarheid waardeur God self sy kerk in stand hou. Die uitdaging vir die kerk is om daarteen te waak dat die institusionalisering van charisma tot ' $\mathrm{n}$ institusionalisme en strukturalisme lei wat op sy beurt tot kanon verhef word.

\section{UITDAGINGS VIR DIE KERK}

Die kerk word voortdurend deur die uitdaging in die gesig gestaar om relevant te bly in 'n wêreld wat aanhou verander. Dít geld onder andere vir die wyse waarop die kerk die Woord verkondig, oor homself dink, oor die Skrif nadink en uitsprake maak, sowel as oor die amp besin. Die kerk is dus voortdurend

20.Van Eck (1991:672-675) voer die argument dat die term presbu/teroj op die sosiale rol van die familiehoof in die eerste-eeuse Mediterreense wêreld dui. Verder rol van beweer Van Eck $(1991.675-679,680)$ dat vier ander terme, naamlik moı $\mu \eta v$ die familiehoo in die huishouding verwys. Daar word ook aangetoon dat hierdie vier begrippe telkens met die sogenaamde 'ampte' in die Nuwe Testament verbind word. 
besig om sekere sake te institusionaliseer. Om relevant te bly het die kerk egter nodig om later te de-institusionaliseer en dan weer te institusionaliseer. Wanneer die kerk opnuut institusionaliseer wat die amp betref, is die uitdaging om dit te doen in pas met wat Jesus ons oor diensbaarheid leer. In die institusionalisering van charisma moet die kerk daarmee rekening hou dat hy kerk is in die 21 ste eeu.

Vaste gewoontes in die uitvoering van ampspligte, soos die kerk dit tradisioneel verstaan, lei tot ' $n$ vaste patroon waarin ampswerk verrig word. Hierdie vaste patrone bepaal in ' $n$ groot mate hoe die institusionalisering van charisma in die kerk plaasvind en wat van ampsdraers in die verrigting van hul ampswerk verwag word.

Kulturele konstrukte het in 'n groot mate die ampsbegrip van die kerk begin bepaal. Hierdie konstrukte word verhef tot kanon, wat die kerk maklik in institusionalisme kan laat vasval.

Daar bestaan verskeie maniere waarop herinstitusionalisering kan plaasvind om ampswerk doeltreffender te maak, sonder om die wese van waaroor dit gaan te verloor. Die uitdaging vir die kerk lê dus daarin om 'nuwe uitvindsels', wat ampswerk doeltreffender sal maak, in werking te stel, sonder om van die werklike bedoeling van die amp, naamlik diensbaarheid, af te wyk.

\section{SLOTOPMERKINGS}

Hierdie artikel het ten doel gehad om die ampsbegrip van die NHKA te meet aan die 'amp', oftewel bedieninge, in die Nuwe Testament, en meer spesifiek Jesus se oproep tot dissipelskap in Markus 8:34. Daar is aangetoon dat die historiese Jesus steeds relevant is vir kerklike teologie, omdat daar ' $n$ saaklike kontinuïteit tussen die historiese Jesus en die kerk van vandag bestaan. Die slotsom is dat Jesus se oproep tot dissipelskap in Markus 8:34 ' $n$ bepaalde ampsbegrip impliseer, waarvan diensbaarheid op grond van selfverloëning, kruisopneming en navolging die kern uitmaak.

Die ampswerk word begrond in charismata wat God deur sy Gees aan mense gee. Hierdie charismata is die basis op grond waarvan dienswerk gedoen word. 'n Onafwendbare proses wat deurgaans in enige groep - ook in die kerk, synde 'n groep gelowiges - plaasvind, is institusionalisering, deinstitusionalisering en herinstitusionalisering.

' $n$ Eietydse ampsbegrip moet in kontinuïteit staan met die Jesussaak. Indien dissipelskap, oftewel diensbaarheid, nie die wese van ampswerk uitmaak nie, is dit nie dienswerk soos wat met die implisiete ampsbegrip in Jesus se oproep tot dissipelskap bedoel is nie.

Vervolgens word ' $n$ paar opmerkings gemaak oor die ampsbegrip van die NHKA:

- Diewesevandieampsbegrip van dieNHKA is diensbaarheid. Dít blyk duidelik uit die bevestigingsformulier vir ouderlinge en diakens, en die Kerkorde. Op grond hiervan kan die stelling gemaak word dat daar 'n saaklike kontinuiteit bestaan tussen die ampsbegrip van die NHKA, en die Jesus-saak.

- Die herkoms van die amp kan teruggevoer word na die beweging rondom Jesus. Wanneer die kerk sy ampsbegrip in die bevestigingsformulier verwoord, behoort die kerk dus meer aandag te gee aan Jesus se oproep tot dissipelskap, omdat dit die kern van ampswerk uitmaak.

- Verskeie kulturele konstrukte het in die verlede tot die vorming van die NHKA se ampsbegrip bygedra, en het ook bepaal hoe die praktiese inkleding van die amp, oftewel die strukture waarin ampswerk gestalte gekry het, lyk.

Bestaande kulturele konstrukte in die NHKA word duidelik sigbaar wanneer die ampswerk van diaken neergelê word as 'n ampsdraer wat offergawes insamel waarmee die gemeente in stand gehou word. In die NHKA is dít waarop die oorwegende klem val wat die ampswerk van diakens betref. Min diakens weet dat die middelpunt van diakenswerk barmhartigheidswerk is. In baie gevalle het diakens tot blote kollekteerders verskraal. Dit is deels toe te skryf aan die kulturele konstruk dat dít is hoe diakenswerk in die verlede ingerig was - 'dít is wat ' $n$ diaken doen'. Hierdie konstruk is gemistifiseer, en diakens glo dus dat dit hulle werk is om offergawes in te samel. Die belangrikste werk van diakens is egter diens by die Nagmaaltafel, barmhartigheidswerk, en die insamel van aalmoese waarmee behoeftiges binne én buite die gemeente versorg word.

- Dit is belangrik dat die institusionalisering van charisma in ' $n$ bepaalde struktuur plaasvind. Ampswerk kry binne hierdie struktuur gestalte. Die gevaar bestaan dat hierdie strukture in kulturele konstrukte verander en tot iets verhef word wat dit nié moet wees nie. Dan loop die kerk gevaar om die strukture ten koste van ampswerk in stand te hou. As dit vir gemeentes nie meer moontlik is om in elke wyk ' $n$ ouderling en diaken te hê nie, gebeur dit soms dat lidmate tot ampsdraers verkies word slegs om hierdie vakatures in die kerkraad te vul. Kerkrade sit dan met ampsdraers wat nie hul ampswerk na behore verrig nie en die situasie net verder bemoeilik. In gevalle soos hierdie kan die struktuur van hoe die gemeente se kerkraad ingerig is eerder aangepas word om die dienswerk in die gemeente doeltreffender te maak. ' $n$ Voorbeeld in hierdie verband is dat elke wyk in die gemeente ' $n$ ouderling het wat by lidmate huisbesoek aflê. Offergawes word in die vorm van debietorders ingesamel, of lidmate kan dit kerk toe bring. Lidmate wat byvoorbeeld hul offergawes deur middel van debietorders gee, word egter nie maandeliks deur 'n diaken besoek nie. Daarbenewens is daar ' $n$ Diakonale Dienskomitee wat in die gemeente funksioneer en op barmhartigheidswerk ingestel is. Op hierdie wyse word ouderling- en diakenswerk steeds in die gemeente verrig, dog in 'n nuwe struktuur en heel doeltreffend.

God gee deur sy Gees aan mense charismata. Hierdie charismata word geïnstitusionaliseer ten einde gehoorsaam te wees aan Jesus se oproep tot dissipelskap, en diensbaar te wees in die kerk. Werklike dienswerk lê dus in die gehoorsame antwoord op Jesus se oproep: 'As iemand agter My aan wil kom, moet hy homself verloën, sy kruis opneem en My volg ...'.

\section{LITERATUURVERWYSINGS}

Bailey, K.E., 2008, Jesus through Middle Eastern eyes: Cultural studies in the gospels [Jesus deur Midde-Oosterse oë: Kultuurstudies in die evangelies], IVP Academic, Downers Grove.

Bartchy, S.S., 2009, 'Jesus of Nazareth, the Pharisees, and Mediterranean manliness' [Jesus van Nasaret, die Fariseërs en Mediterreense manlikheid], unpublished paper read at the 2009 annual meeting of the Context Group, Niagara Falls, New York, 19-22 March.

Berger, P.L. \& Luckmann, T., [1967] 1975, The social construction of reality: A treatise in the sociology of knowledge [Die sosiale konstruksie van die werklikheid: ' $n$ verhandeling in die sosiologie van kennis], Penguin, Harmondsworth.

Best, E., 1981, 'Following Jesus: Discipleship in the Gospel of Mark' [Om Jesus te volg: Dissipelskap in die evangelie van Markus], Journal for the study of the New Testament Supplement Series 4, University of Sheffield, Sheffield.

Crook, Z., 2008, 'Renovating the house that Bruce built: Remodelling ascribed and acquired honor', paper presented at the meeting of the Context Group, Portland, Oregon, 6-8 March 2008.

Crossan, J.D., 1991, The historical Jesus: The life of a Mediterranean Jewish peasant [Die historiese Jesus: Die lewe van 'n Mediterreense Joodse boer], Harper Collins, New York.

Crossan, J.D., 1998, The birth of Christianity: Discovering what happened in the years immediately after the execution of Jesus [Die geboorte van die Christendom: Ontdek wat gebeur het in die jare onmiddellik ná die teregstelling van Jesus], Harper Collins, New York. 
Cuppit, D., 2001, 'Reforming Christianity' [Die hervorming van die Christendom], in J.K. Armstrong, et al. (eds.), The once and future faith [Die gewese en toekomstige geloof], pp. 51-64, Polebridge Press, Santa Rosa.

Dreyer, Y., 2002, 'Perspectives on leadership. Leadership in the world of the Bible: (De)institutionalisation as an ongoing process [Perspektiewe op leierskap. Leierskap in die wêreld van die Bybel: (De)institusionalisering as ' $n$ deurlopende proses]', Verbum et Ecclesia 23(3), 625-641.

Dunn, J.D.G., 1977, Unity and diversity in the New Testament. An inquiry into the character of earliest Christianity [Eenheid en verskeidenheid in die Nuwe Testament. 'n Ondersoek na die karakter van die vroegste Christendom], SCM Press, London.

Horsley, R.A. \& Hanson, J.S., 1985, Bandits, prophets and messiahs [Bandiete, profete en messiasse], Winston Press, Minneapolis.

Kingsbury, J.D., 1983, The Christology of Mark's Gospel [Die Christologie van die Evangelie volgens Markus], Fortress Press, Philadelphia.

Malina, B.J., 1981, The New Testament world. Insights from cultural anthropology [Die Nuwe Testament wêreld. Insigte uit die kulturele antropologie], Westminster, Louisville.

Malina, B.J., 1995, 'Early Christian groups. Using small group formation theory to explain Christian organizations' [Vroeg Christelike groepe. Die gebruik van die kleingroepvormingsteorie om Christelike organisasies te verduidelik], in P.F. Esler (ed.), Modelling early Christianity. Social-scientific studies of the New Testament in it's context, pp. 96-113, Routledge, New York.

Malina, B.J., 2001, The social gospel of Jesus. The kingdom of God in Mediterranean perspective [Die sosiale evangelie van Jesus. Die koninkryk van God in Mediterreense perspektief], Fortress Press, Minneapolis.

Matera, F.J., 1987, What are they saying about Mark? [Wat sê hulle oor Markus?], Paulist Press, Mahwah.

Myers, C., 1988, Binding the strong man: A political reading of Mark's story of Jesus [Die binding van die sterk man: ' $\mathrm{n}$ Politieke lees van Markus se verhaal oor Jesus], Orbis, New York.

Nederduitsch Hervormde Kerk van Afrika, 2009, Diensboek, Kital, Pretoria.

Petersen, N.R., 1985, Rediscovering Paul: Philemon and the sociology of Paul's narrative world [Herontdek Paulus: Filemon en die sosiologie van Paulus se verhaal], Fortress Press, Philadelphia.
Räisänen, H., 1990, The 'Messianic secret' in Mark [Die 'Messiaanse geheime' in Markus], transl. C. Tuckett, T \& T Clark, Edinburgh.

Saldarini, A.J., 1988, Pharisees, scribes and Sadducees in Palestinian society. A sociological approach [Fraiseërs, skrifgeleerdes en Sadduseërs in die Palestynse sameleweing. ' $n$ Sosiologiese benaderingl, Glazier, Delaware.

Van Aarde, A.G., 1994, Kultuurhistoriese agtergrond van die Nuwe Testament. Die eerste eeuse Mediterreense sosiale konteks, Kital, Pretoria.

Van Aarde, A.G., 2000, 'Die relevansie van die historiese Jesus ondersoek vir kerklike teologie', HTS Teologiese Studies/ Theological Studies 56(2\&3), 549-571.

Van Aarde, A.G. \& Van Eck, E., 2007, 'Christologie: Historiese Jesus-navorsing', ongepubliseerde studiehandleiding, Universiteit van Pretoria, Pretoria.

Van Eck, E., 1991, "n Sosiaal wetenskaplike ondersoek na die "amp" van ouderling in die Nuwe Testament', HTS Teologiese Studies/Theological Studies 47(3), 656-684.

Van Eck, E., 1995, Galilee and Jerusalem in Mark's story of Jesus. A narratological and social scientific reading, HTS Supplementum 7, Kital, Pretoria.

Van Eck, E., 2007, 'Die huwelik in die eerste eeuse Mediterreense wêreld (III): Jesus en die huwelik', HTS Teologiese Studies/ Theological Studies 63(2), 481-513.

Van Eck, E., 2009, 'Inklusiwiteit as evangelie', HTS Teologiese Studies/Theological Studies 65(1), 466-475.

Van Iersel, B.M.F., 1982, 'De betekenis van Marcus vanuit syn topografische struktuur [Die betekenis van Markus beskou vanuit sy topografiese struktuur], Tijdschrift vir Theologie $22,117-138$.

Van Iersel, B.M.F., 1983, 'Locality, structure and meaning in Mark' [Ligging, struktuur en betekenis in Markus], Linguistica Biblica 53, 45-54.

Van Iersel, B.M.F., 1989, Reading Mark [Die lees van Markus], The Liturgical Press, Collegeville.

Waetjen, H.C., 1989, A recording of power: A socio-political reading of Mark's Gospel ['n Optekening van mag: 'n Sosiopolitieke lesing van Markus se evangelie], Fortress, Minneapolis.

Weeden, T.J., [1971] 1979, Mark - traditions in conflict [Markus - tradisies en konflik], Fortress Press, Philadelphia.

Wrede, W., 1971, The Messianic secret [Die Messiaanse geheim], transl. J.C.G. Greig, James Clarke \& Co., Cambridge. 